\title{
Szárazságstressz és mikorrhiza gombák búza gyökérnövekedésére gyakorolt hatásának monitorozása elektromos kapacitás mérésével
}

\author{
CSERESNYÉS Imre, TAKÁCS Tünde, KovÁCs Ramóna, FÜZY Anna, RAJKAI Kálmán \\ Magyar Tudományos Akadémia, Agrártudományi Kutatóközpont, Talajtani és \\ Agrokémiai Intézet, Budapest
}

(Beérkezett: 2018. április 20.; elfogadva: 2018. október 2.)

\section{Bevezetés}

A hagyományos gyökérvizsgálati eljárásokkal kapcsolatos módszertani problémák következtében az in situ technikák alkalmazása és fejlesztése a növénytani kutatás számos területén kiemelt fontosságú (MILCHUNAS, 2012). A roncsolásmentes módszerek közé sorolható a gyökér-talaj rendszer elektromos kapacitásának $\left(C_{R}\right)$ mérése, mely a gyökérközegbe szúrt talajelektród és a növény szárára rögzített növényelektród között váltakozó árammal $(1 \mathrm{kHz}, 1 \mathrm{~V})$ mérhető kapacitás és a gyökérzet mérete (tömeg, hossz) közötti korreláción alapul (CHLOUPEK, 1972). A gyökérszöveten áthaladó áram a membránok elektromos polarizációját (töltéstárolás) és relaxációját, valamint ennek eredményeként az áram amplitúdójának és fázisának változását okozza. A módszer elektromos alapjait leíró modellek a gyökérzetet hengerkondenzátorok rendszerének tekintik, melyben a membránok párhuzamosan kapcsolt töltéstároló dielektrikumokként a felületükkel arányos nagyságú kapacitást alkotnak (DALTON, 1995; RAJKAI et al., 2005; ElLIS et al., 2013).

Gyorsaságán és egyszerüségén túl az eljárás előnye, hogy a víz- és ionfelvétel szempontjából inaktív (szuberinizálódott) gyökérrégiók hozzájárulása a mérhető kapacitáshoz lényegesen kisebb, mint az abszorptív szegmenseké, így a mért $C_{R}$ a gyökérzet méretén túl annak müködéséröl is hordoz információt (CSERESNYÉS et al., 2016). Jelentős hátránya azonban, hogy a talaj tulajdonságai (textúra, ionösszetétel, szervesanyag-tartalom stb.), vízállapota, valamint a növényelektród elhelyezése lényegesen befolyásolják a mérési eredményt, így az adatok csak azonos növényfaj, talajtípus és vízállapot esetén hasonlíthatóak össze (OZIER-LAFONTAINE \& BAJAZET 2005; ELLIS et al., 2013). Ugyanakkor megfelelően beállított kísérleti körülmények között (azonos vízállapotú, homogén közeg, pontos elektród-elhelyezés) a módszerrel gyorsan és viszonylag megbízhatóan becsülhető a gyökérrendszer mérete és aktivitása (PosTiC \& DOUSSAN, 2016). Korlátai miatt az eljárást rendszerint tenyészedény-kísérletekben alkalmazzák, de homogén talajviszonyok között szabadföldön is megbízható eredménnyel használható (HEŘMANSKÁ et al., 2015).

Mivel a $C_{R}$ mérése a növényt nem károsítja, így a gyökérnövekedés időbeli nyomon követésére is lehetöséget nyújt. Összehasonlító vizsgálatokban a módszert felhasználták a gyökérfejlődést gátló környezeti tényezők, pl. nehézfém-szennyezés

Postai cím: CSERESNYÉs IMRE, Magyar Tudományos Akadémia, Agrártudományi Kutatóközpont, Talajtani és Agrokémiai Intézet, 1022 Budapest, Herman Ottó út 15 E-mail: cseresnyes.imre@agrar.mta.hu 
vagy szárazságstressz hatásának monitorozására (VAMERALI et al., 2009; CSERESNYÉS et al., 2016). A gyökérszimbionta arbuszkuláris mikorrhiza gombák (AMF) kolonizációja - a megnövekedett gyökér-talaj kontaktfelületnek, valamint az intenzívebb víz- és tápanyagfelvételnek köszönhetően - szintén detektálható a $\mathrm{C}_{\mathrm{R}}$ mérésével (CSERESNYÉS et al., 2013).

Munkánkban vizsgáltuk, hogy a szárazságstressz és az AMF-oltás - külön és együttesen - milyen hatást fejt ki különböző búzafajták gyökérfejlődésére, valamint, hogy az esetlegesen fajtaspecifikus változások hogyan követhetők a $C_{R}$ mérésével. A tenyészedény-kísérletekkel elsősorban a gyökérkapacitás-mérés alkalmasságát, valamint egyéb módszerekkel (sztómakonduktancia, klorofilltartalom mérése) történő együttes használatát mutatjuk be.

\section{Anyag és módszer}

A tenyészedény-kísérletet búza (Triticum aestivum L.) egy őszi (cv. Mv. Hombár; jele: $M$ ) és egy tavaszi (cv. TC 33; jele: $T$ ) fajtájával végeztük. A magvakat Petri-csészékben, nedves vattapapíron 2 napig, $27{ }^{\circ} \mathrm{C}$-on, sötétben csíráztattuk. A csíranövényeket (az öszi búza esetén 6 hetes, $+4{ }^{\circ} \mathrm{C}$-os vernalizációt követően) 1,25 l-es edényekbe ültettük; nevelőközegként 1,1 kg pumicit-őrleményt $(\mathrm{pH}=6,53)$ alkalmaztunk. Az edények felének közegét egyenként $10 \mathrm{~g}$, pumicit alapú AM-gomba (Diversispora epigaea; BEG 47) oltóanyag rétegezésével oltottuk $[M(+)$ és $T(+)$ növények] az oltatlan csoportok $[M(-)$ és $T(-)]$ mellett. (A $D$. epigaea az elvégzett elökísérletek során pumicit közegben magas gyökérkolonizációs értékeket mutatott.)

A növényeket fényszobában 48 napig neveltük $26 / 18{ }^{\circ} \mathrm{C}$ és $16 / 8$ óra nappali/éjszakai hőmérséklet és fényintenzitás $\left(\sim 500 \mu \mathrm{mol} / \mathrm{m}^{2} / \mathrm{s}\right)$ mellett. A növények felének $[M W(-), M W(+), T W(-), T W(+) ; \mathrm{n}=12]$ optimális vízellátást biztosítottunk: közegüket csapvízzel naponta szabadföldi vízkapacitásig $(0.21$ $\left.\mathrm{cm}^{3} / \mathrm{cm}^{3}\right)$ öntöztük, tápanyag-ellátásukat hetente $150 \mathrm{ml}$ P-szegény $(0,5 \mathrm{mM}$ $\mathrm{KH}_{2} \mathrm{PO}_{4}$ ) Hoagland-oldattal biztosítottuk. A növények másik felét $[M D(-), M D(+)$, $T D(-), T D(+)]$ a 14 . és 33. nap között szárazságstressznek tettük ki: az öntözést megszüntetve a közeg víztartalmát hervadáspontig $\left(0.13 \mathrm{~cm}^{3} / \mathrm{cm}^{3}\right)$ csökkentettük, majd napi vízpótlással kevéssel e feletti értéken tartottuk. A nedvességtartalmat (v/v\%) Trime-HD2 típusú TDR müszerrel (IMKO GmbH., Ettlingen, Germany) ellenőriztük. A növénytáplálást hetente $30 \mathrm{ml}$ ötszörös töménységü Hoaglandoldattal végeztük.

A gyökérkapacitást GW-8101G LCR-müszerrel (Gw Instek Co. Ltd., Taiwan) mértük $1 \mathrm{kHz}$ frekvencián, $1 \mathrm{~V}$ feszültséggel, párhuzamos eredő kapacitásként. Talajelektródként $6 \mathrm{~mm}$ átméröjü, $15 \mathrm{~cm}$ hosszú acélrudat, növényelektródként a szárra $10 \mathrm{~mm}$ magasságban elhelyezett csipeszt alkalmaztunk. A csipeszt $5 \mathrm{~mm}$ széles alufólián keresztuil rögzítettük, mely alatt a szárat áramvezető géllel kentük körbe. A mérést mindig a pumicit szabadföldi vízkapacitásra öntözését követően végeztük. Az optimálisan öntözött növényeknél hetente (13-48. nap), a stresszelt példányok esetén a szárazságkezelés végétől kezdődően három alkalommal $(34,41$. és 48. nap). 
A szárazságsztressz végén mértük a növények sztómakonduktanciáját $\left(g_{\mathrm{s}}\right)$ a legfiatalabb kifejlett levélen, Decagon SC-1 típusú porométerrel (Decagon Devices Inc., Pullman, WA, USA). A kísérlet végén (48. nap) meghatároztuk a klorofilltartalmat, szintén a legfiatalabb kifejlett levélen, Minolta SPAD-502 készülékkel (Konica Minolta Inc., Osaka, Japán) növényenként hat ismétlésben (UDDLING et al., 2007).

Az utolsó $C_{R}$ mérés után a hajtást levágtuk, a gyökérzetet a közegből folyóvízzel óvatosan kimostuk, és nedves tömegét mértük. A hajszálgyökerekből random módon mintát vettünk, melyböl a gyökerek vitalitását a dehidrogenázaktivitást mutató TTC (2,3,5-trifenil-tetrazólium-klorid)-teszttel határoztuk meg (GONDOR et al., 2013). Hajszálgyökér-mintákon vizsgáltuk az AM-gomba gyökérkolonizációját anilinkékkel festés után (PHILLIPS \& HAYMAN, 1970), fénymikroszkóppal (40-200×). TROUVELOT et al. (1986) módszerével becsültük az AMF-kolonizáció intenzitását (M\%) és a szimbiózis hatékonyságát mutató arbuszkuláltságot $(\mathrm{A} \%)$. A levágott hajtást és a gyökérzet fennmaradó részét $70{ }^{\circ} \mathrm{C}$ on súlyállandóságig szárítottuk, majd száraz tömegét meghatároztuk.

Az adatok elemzésére a Statistica programot (ver. 12) használtuk. A búzafajták közötti különbségeket, valamint a szárazságstressz és az AMF kolonizáció hatását kétmintás $t$-próbával vizsgáltuk a mért növényi paraméterekre vonatkozóan. A csoport szórások szignifikáns különbsége esetén az értékelést Welch $t$-teszttel végeztük. Szignifikáns különbséget $\mathrm{p}<0,05$ esetén fogadtunk el. $\mathrm{A} \mathrm{C}_{\mathrm{R}}$ és a gyökértömeg közötti korrelációt lineáris regresszióanalízissel vizsgáltuk. A regressziós egyenesek összehasonlításához F-próbát használtunk, feltételezve a két egyenes tengelymetszetének és meredekségének egyenlöségét.

\section{Eredmények}

A korai egyedfejlődési szakaszban (13-27. nap) a $T$ búzafajta gyökérkapacitása $\left(\mathrm{C}_{\mathrm{R}}\right)$ minden esetben kisebb volt, mint az $M$ fajtáé (1. ábra), de a különbség (6-12\%) csak az AM-gombával oltott növényeknél volt szignifikáns. Ezt követően (34-41. nap) minden kezelésnél szignifikáns különbséget találtunk. A kísérlet végére a $T$ fajta $C_{R}$-je oltás nélkül $12 \%$-kal, oltás mellett $18-23 \%$-kal volt alacsonyabb. Az AM gombával oltásnak csak az utolsó mérési napon volt hatása a $\mathrm{C}_{\mathrm{R}}$-re: az oltott növények kapacitása szignifikánsan (10-23\%-kal) kisebb volt, mint az oltatlanoké. A különbség jelentősebb volt a $T$ fajta esetén. A szárazságstressz hatására minden esetben szignifikánsan csökkent a $C_{R}$. A vízmegvonást követően (34. nap) 14-20\%-os csökkenést tapasztaltunk, majd a különbség a kísérlet végére mérséklődött. 


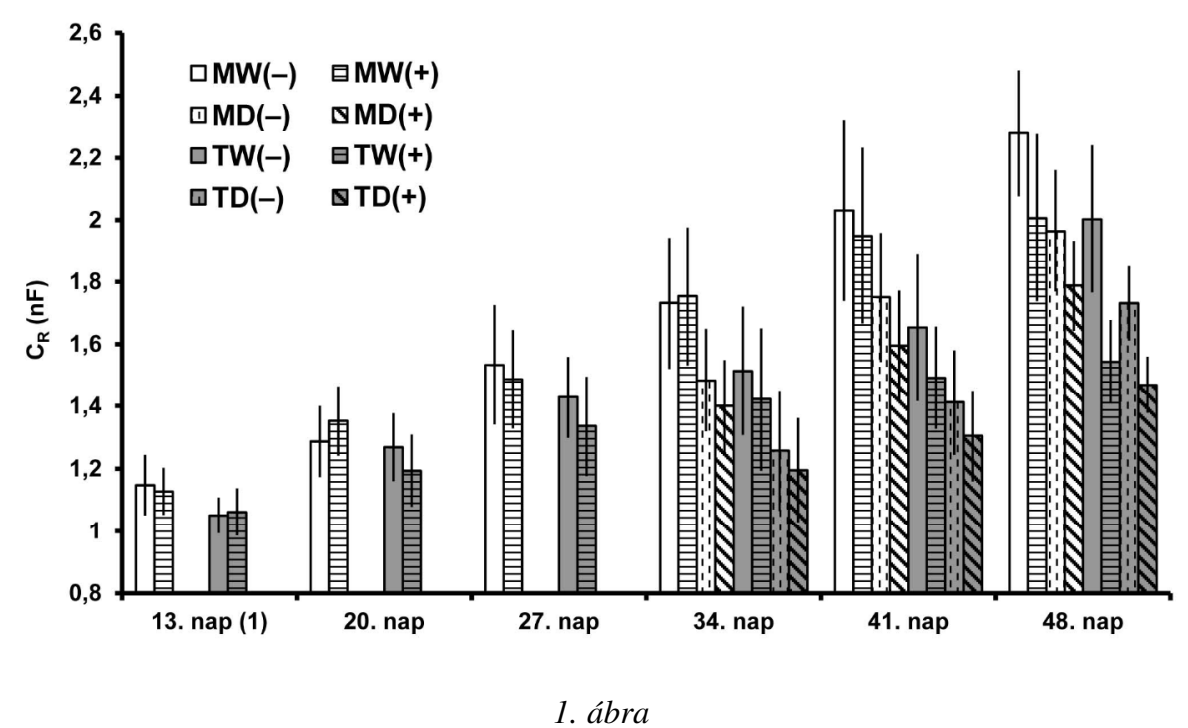

A gyökér elektromos kapacitásának $\left(\mathrm{C}_{\mathrm{R}}\right.$; nanofarad egységben) átlaga és szórása a növény korának függvényében különböző búzafajtákban ( $M$ és $T)$, optimális vízellátás $(W)$ és szárazságstressz $(D)$ mellett, oltatlan (-) és arbuszkuláris mikorrhiza gombával oltott (+) növények esetén.

A sztómakonduktanciában $\left(g_{\mathrm{s}}\right)$ optimális vízellátás mellett nem volt különbség a búzafajták között (2/A ábra). Szárazságstressz mellett azonban a $T$ fajtánál szignifikánsan nagyobb $g_{\mathrm{s}}-\mathrm{t}$ mértünk. Az AMF oltás a jól öntözött növények $\mathrm{g}_{\mathrm{s}}$ értékét szignifikánsan növelte (az $M$ fajtáét 55\%-kal, a $T$ fajtáét 43\%-kal), míg szárazságstressz alatt az oltásnak nem volt hatása. A vízmegvonás - az $M W(+)$ és $M D(+)$ csoportok kivételével - nem csökkentette szignifikánsan a $g_{\mathrm{s}} \mathrm{t}$.

A SPAD-értékben kifejezett klorofilltartalom minden kezelésben szignifikánsan (11-21\%-kal) kisebb volt a $T$ búzafajta leveleiben (2/B ábra). Az AMF oltás a $T W$ növények klorofillmennyiségének szignifikáns növekedését eredményezte, más kezelésekben viszont nem volt hatása. A szárazságstressz nem befolyásolta az $M$ fajta klorofilltartalmát, a $T$ fajtáét azonban - az AMF kezeléstől függetlenül - szignifikánsan növelte.

A TTC-teszt nem mutatott különbséget a búzafajták gyökér-vitalitásában $(2 / C$ ábra). Az AM gomba hatására optimális vízellátás mellett az enzimaktivitás jelentősen nőtt (94\%-kal az $M$ és 74\%-kal a $T$ fajtánál), míg szárazságstressz alatt a növekedés csak az M fajtánál bizonyult szignifikánsnak. A szárazság minden kezelésben csökkentette a gyökér életképességét, de a változás csak az $M$ fajta oltott növényeinél volt szignifikáns. 

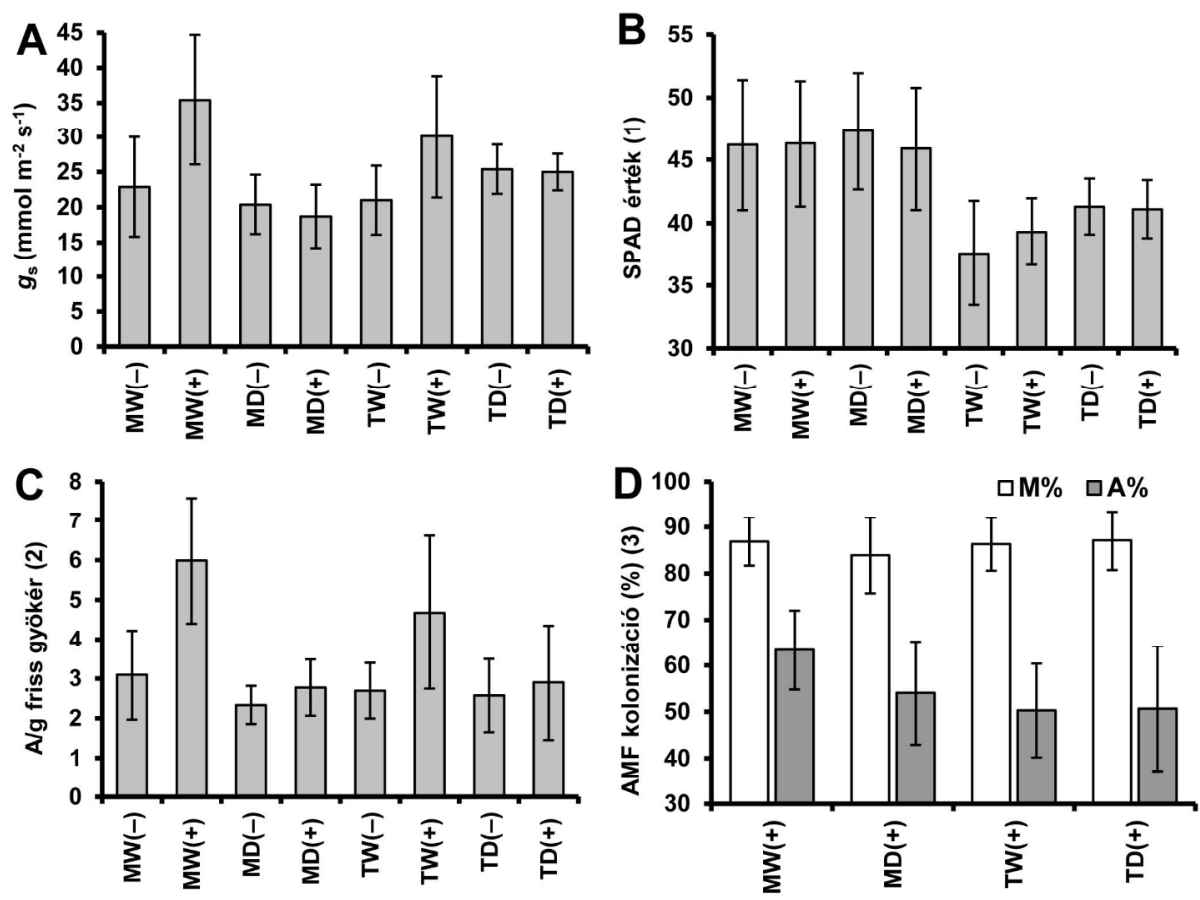

2. ábra

(A) A sztómakonduktancia $\left(g_{\mathrm{s}}\right)$, (B) a SPAD értékben kifejezett klorofilltartalom, (C) a gyökér-életképesség (TTC-teszt során mért abszorbancia), valamint (D) az AMF gyökérkolonizáció intenzitása (M\%) és az arbuszkuláltság (A\%) átlagai és szórásai különböző búzafajtákban ( $M$ és $T)$, optimális vízellátás $(W)$ és szárazságstressz $(D)$ mellett, oltatlan (-) és AM-gombával oltott (+) növények esetén.

A tenyészidő végén a gyökérminták mikroszkópos vizsgálata az AM gomba kolonizáció magas intenzitását $(\mathrm{M}=84-87 \%)$ mutatta ki, viszonylag jelentős arbuszkuláltság $(\mathrm{A}=50-63 \%)$ mellett $(2 / D$ ábra $)$. Szignifikáns különbséget a kezelések között egyik mutatóban sem találtunk, azonban öntözés mellett az $M$ fajta arbuszkuláltsága 13\%-kal magasabb volt, mint a $T$ fajtáé, és ezt a szárazságstressz valamelyest (9\%-kal) csökkentette.

A $T$ fajta gyökér száraztömege kezeléstől függetlenül szignifikánsan (37-52\%kal) kisebb volt, mint az $M$ fajtáé (3/A ábra). A gyökértömeg az összes kezelésben szignifikánsan csökkent mind az AMF oltás hatására (29-42\%-kal), mind a szárazság következtében (9-35\%-kal; a $T W(+)$ és $T D(+)$ csoportok közötti eltérés nem szignifikáns). A hajtás száraztömege ugyanakkor szignifikánsan (16-29\%-kal) nagyobb volt a $T$ búzafajtánál (kivéve az $M W(+)$ és $T W(+)$ csoportokat). A hajtás tömege - a gyökéréhez hasonlóan - szignifikánsan (26-45\%-kal) csökkent az AMF oltás hatására, valamint szárazságstressz alkalmazásakor (6-37\%-kal; $T W(+)$ és $T D(+)$ kezeléseknél nem szignifikáns). 

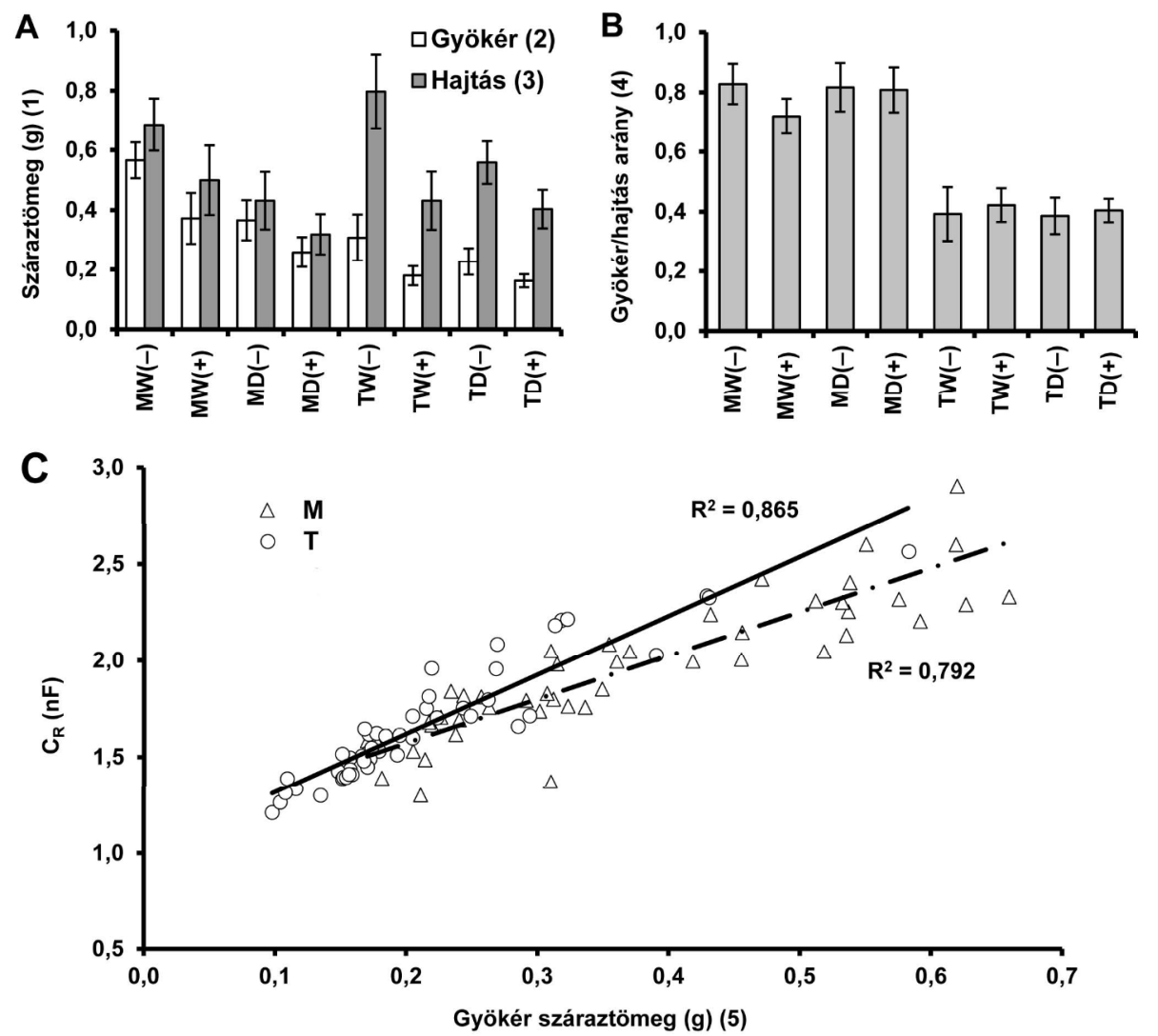

3. ábra

(A) A gyökér- és hajtástömeg, valamint (B) a gyökér/hajtás arány átlagai és szórásai különböző búzafajtákban ( $M$ és $T)$, optimális vízellátás $(W)$ és szárazságstressz $(D)$ mellett, oltatlan (-) és AM-gombával oltott (+) növények esetén. (C) A gyökér elektromos kapacitása $\left(\mathrm{C}_{\mathrm{R}}\right)$ és száraztömege közötti összefüggés az $M$ (szaggatott vonal) és $T$ (folytonos vonal) búzafajták esetén.

A gyökér/hajtás arány minden kezelésben jelentősen nagyobb értékü $(0,72-0,83)$ volt az $M$, mint a $T$ fajtánál $(0,39-0,42 ; 3 / B$ ábra $)$, vélhetően az utóbbi korábbi virágzásának köszönhetően. Az AM gomba kolonizációja és a szárazságkezelés nem befolyásolta a gyökér/hajtás arányt, bár az $\mathrm{MW}(+)$ kezelésben kisebb értéket mutattunk ki, mint a fajta többi csoportjában.

A regresszióanalízis szoros lineáris összefüggést mutatott ki a gyökérzet száraztömege és elektromos kapacitása között az $M$ fajta $\left(\mathrm{R}^{2}=0,792 ; \mathrm{F}=171,7\right.$; $\mathrm{p}<0,01)$, és a $T$ fajta $\left(\mathrm{R}^{2}=0,865 ; \mathrm{F}=266,5 ; \mathrm{p}<0,01\right)$ esetén egyaránt $(3 / C$ ábra $)$. Az egyenesek y-tengelymetszete ( $M$ fajta: $1,11 \mathrm{nF} ; T$ fajta: $1,01 \mathrm{nF}$ ) szignifikánsan nem különbözött egymástól, a $T$ fajta meredeksége $\left(3,06 \mathrm{nF} \mathrm{g}^{-1}\right.$ gyökér) azonban 
szignifikánsan nagyobb volt, mint az $M$ fajtáé $\left(2,27 \mathrm{nF} \mathrm{g}^{-1}\right.$ gyökér; $\mathrm{F}_{1,94}=8,55$; $\mathrm{p}<0,01)$.

\section{Az eredmények értékelése}

A kísérleti kezelésként alkalmazott erős szárazságstressz a búzafajták gyökértömegének szignifikáns csökkenését eredményezte, mely a $C_{R}$-értékekben is jól tükröződött. $A C_{R}$-mérések nemcsak a stressz hatását, hanem a növények ezt követő regenerációját is kimutatták: a vízhiány - kezeléstöl függően - a $C_{R}$ 14-20\%-os csökkenését eredményezte, mely különbség a következö méréskor (41. nap) 13-18\%-ra, végül (48. nap) 5-14\%-ra mérséklődött (az oltott $T$ fajtánál már nem volt szignifikáns). Az adatok a $T$ fajta jobb regenerációs képességét mutatták. A várakozással ellentétben, az AMF-el oltott növények $C_{R}$-értékei a nem mikorrhizás növényekhez képest kisebb értékủek voltak, a mikorrhiza-hatás csupán a kísérlet utolsó hetében jelentkezett. Ennek megfelelően az oltott növények biomasszája is kisebb volt.

Az AMF kolonizáció - föleg stresszterhelt környezetben - rendszerint növeli a gazdanövény biomasszáját, többek között a víz- és tápanyagfelvétel fokozása révén (AUGÉ, 2001; PELLEGRINO et al., 2015). Ugyanakkor a szimbiózis gyakran nincs hatással a gazdanövény biomasszájára, esetenként pedig csökkenti annak produkcióját (LI et al., 2006; SMITH \& SMITH, 2012). A kétirányú tápanyagátadáson alapuló szimbiózis hatékonysága, illetve a növényi „költség/haszon arány” jelentősen függ a gazdanövény fajától és genotípusától, a gombatörzstől, a talajjellemzőktől (vízállapot, tápanyagtartalom), valamint a környezeti tényezőktől és stresszhatásoktól (AL-KARAKI et al., 2004; TAKÁCS, 2012). A növény fotoasszimilátumainak akár 4-20\%-át is fordíthatja a gomba fenntartására (PARNISKE, 2008). Optimális növénytáplálás mellett a nagy abszorptív gyökérfelületủ növények, így a pázsitfüfélék mikorrhizaképzés iránti fogékonysága alacsony (TAWARAYA, 2003). Erős szárazságstressz alatt az AMF szimbiózis negatív hatású is lehet a gazdanövényre, elsősorban a gombapartner szénhidrátigénye következtében (BRYLA \& DUNIWAY, 1997; CHO et al., 2006). A gombahatás búza esetében fokozottan érvényesülhet a kései vegetatív és a korai reproduktív fenofázisokban, egyrészt a csökkenő fotoszintetikus aktivitás, valamint a gyökér csökkenő szénhidrát-ellátottsága miatt (AL-KARAKI et al., 2004; LI et al., 2008). A kísérletben kimutatott, 84-87\%-os AMF kolonizációs intenzitás a szakirodalomban közölt, 24-82\%-os értékeknél (RYAN et al, 2005; LI et al. 2006; TALAAT \& SHAWKY 2014) magasabb, mely - a kiterjedt arbuszkuláltsággal együtt - tovább fokozhatta a gombák gazdanövényre gyakorolt negatív hatását. Az AM gombák gyökérbeni jelenlétének a biomassza-produkció csökkenésében realizálódó negatív hatását az is alátámasztja, hogy a gazdanövény ráutaltságát jelző AMF kolonizáltsági mutatók a szárazságstressz hatására nem nőttek.

Méréseink szerint az AMF kolonizáció optimális öntözés mellett növelte a sztómakonduktanciát, ugyanakkor e hatás szárazságstressz mellett nem érvényesült. Ez megfelel a különböző búzafajták vizsgálata során kapott korábbi eredményeknek (BRYLA \& DUNIWAY, 1997; TALAAT \& SHAWKY, 2014). A SPAD-érték 
tekintetében elsősorban a két búzafajta között mutattunk ki különbséget, ami az eltérő klorofilltartalom mellett a levelek morfo-anatómiai különbségeire is visszavezethető (UDDLING et al., 2007; MONOSTORI et al., 2016). A TTC-teszt a kolonizált gyökerek nagyobb vitalitását mutatta ki, amely az AMF jelenlétében felfokozott növényi anyagcsere és a gyökérasszociált gomba-dehidrogenáz aktivitás együttes hatásából adódhat. A szárazságstressznek kitett gyökerek TTC-teszt mutatta életképessége csökkent, ez a különbség azonban több esetben nem volt szignifikáns. Ezzel összefüggésben, CLEMENSSON-LiNDELL (1994) megállapította, hogy a TTC-teszttel kimutatható a gyökér életképességének stresszindukált csökkenése, azonban a módszer érzékenysége gyakran nem elegendő a hatás detektálásához.

A két búzafajta szárazságstresszre, illetve AMF kolonizációra adott válaszában számottevő különbségeket nem tudtunk kimutatni az élettani mutatók tekintetében. A sztómakonduktancia és a TTC-teszt alapján azonban a $T$ fajta szárazságtürése valamelyest nagyobbnak tekinthető. Ezzel összhangban, a teljes biomassza szárazságkezelés hatására bekövetkezett csökkenése a $T$ fajta esetén kisebb mértékủ (8-29\%) volt, mint az $M$ fajtáé (34-36\%), különösen AMF oltás mellett (összhangban a $\mathrm{C}_{\mathrm{R}}$-ben bekövetkezett változásokkal).

A mért $C_{R}$ és a gyökér száraztömege közti regressziók (3/C ábra) alapján az elektromos kapacitás mérésével a gyökérzet mérete megbízhatóan becsülhető. A $T$ búzafajta regressziós egyenesének szignifikánsan nagyobb meredeksége a fajta kisebb gyökér/hajtás arányával magyarázható. Ennek valószínüsíthető következménye az egységnyi gyökértömegre és -felületre eső nagyobb hajtástömeg, mely jelentősebb transzspirációt, ezáltal intenzívebb vízfelvételt eredményez. Ez a fajlagos vízfelvételi ráta és a fajlagos $C_{R}\left(\mathrm{nF} \mathrm{g}^{-1}\right.$ gyökér) növekedéséhez vezet. Korábbi vizsgálatainkban hasonló összefüggést állapítottunk meg nyolc szójafajta vízfelvételének és gyökérkapacitásának monitorozásakor (CSERESNYÉS et al., 2016). Mindez a kapacitásmérés egyik elönyét is mutatja: a $C_{R}$ a gyökérzet aktivitásától is függ, így egy "funkcionális gyökérméretet" mutatva a gyökérzetet puszta méreténél jobban jellemzi. Esetünkben a $C_{R}$ változása érzékenyebbnek bizonyult a stresszhatás detektálása szempontjából, mint a gyökérmintákon végzett TTC-teszt. A fajlagos gyökérméretben mutatkozó esetleges különbségek ugyanakkor felhívják a figyelmet a kalibrációk fontosságára a különbözö növényfajtákkal végzett összehasonlító vizsgálatok $C_{R}$-méréseinek értékelésekor.

A bemutatott kísérlet igazolja, hogy a gyökérkapacitás mérése alkalmas a gyökérnövekedés monitorozására, a fajtaspecifikus különbségek detektálására, valamint a környezeti tényezők gyökérfejlödésre gyakorolt hatásának kimutatására. A roncsolásmentes eljárás egyéb növényfiziológiai és -anatómiai mérésekkel párhuzamosan jól használható, és jelentős információt nyújt a genetikai jellemzők és környezeti tényezők által befolyásolt gyökérnövekedés összehasonlító vizsgálatára során. Fontos kiegészítő módszer lehet a gyökérzet struktúráját, illetve növekedését vizsgáló egyéb eljárások (pl. minirizotron) alkalmazása mellett, de szerepet kaphat egyes gyökérkárosítók detektálásában is. 


\section{Összefoglalás}

Tenyészedény-kísérletben vizsgáltuk, hogy a szárazságstressz és az arbuszkuláris mikorrhiza gomba (AMF) oltás milyen változást okoz a búza gyökérnövekedésében, és ez hogyan követhető nyomon a gyökér-talaj rendszer elektromos kapacitásának $\left(\mathrm{C}_{\mathrm{R}}\right)$ in situ mérésével.

A kísérletet randomizált blokk elrendezésben végeztük két búzafajtával (Mv. Hombár öszi és TC 33 tavaszi), kétféle öntözéssel (optimális és szárazságstressz) és kétféle oltással (oltatlan és AM-gombával oltott), 12 ismétlésben. A tenyészidőszakban monitoroztuk a $\mathrm{C}_{\mathrm{R}}$-t, valamint mértük a sztómakonduktanciát és a levelek klorofilltartalmát (SPAD-értékben). A kísérlet végén TTC-teszttel vizsgáltuk a gyökerek életképességét, mikroszkópos vizsgálattal becsültük az AM gomba gyökérkolonizációját, valamint meghatároztuk a gyökér- és hajtástömeget.

A vízhiány szignifikánsan (9-35\%-kal) csökkentette a búzafajták gyökértömegét, mely a mért $C_{R}$-értékekben is tükrözödött. A szárazság okozta $C_{R}$ és biomassza-csökkenés jelentősebb volt a TC 33, mint az Mv. Hombár esetében. A $\mathrm{C}_{\mathrm{R}}$ monitorozásával kimutattuk a növények stressz utáni regenerációját és a fajták eltérö gyökérnövekedési dinamikáját. Az AMF oltás csökkentette a $C_{R}$-t és a biomassza-produkciót (29-42\%-kal), vélhetően az intenzív (84-87\%-os) gyökérkolonizáció és a növénynevelés körülményei (erős szárazságstressz) következtében. Az oltás optimális öntözés mellett növelte a sztómakonduktanciát és a gyökér vitalitását. A vízhiány azonban csökkentette a gyökér életképességét. A klorofilltartalom leginkább a búzafajták között mutatott eltérést az Mv. Hombár nagyobb SPAD-értékével. A gyökértömeg és -kapacitás között szoros lineáris korrelációt $\left(\mathrm{R}^{2}=0,792-0,865\right)$ találtunk. A TC 33 fajta regressziós egyenesének nagyobb meredeksége a nagyobb hajtástömegből eredő nagyobb fajlagos vízfelvételre vezethető vissza.

Eredményeink alapján a $C_{R}$-mérés alkalmas a gyökérnövekedési dinamika monitorozására és a környezeti hatások detektálására. A roncsolásmentes eljárás egyéb növénymorfológiai és -élettani vizsgálómódszerek hasznos kiegészítője lehet.

Kulcsszavak: arbuszkuláris mikorrhiza gomba (AMF), elektromos kapacitás, gyökéraktivitás, gyökérnövekedés, szárazságstressz

Rövidítések: AMF - arbuszkuláris mikorrhiza gomba; $C_{R}$ - gyökér-talaj rendszer elektromos kapacitása; $g_{\mathrm{s}}$ - sztómakonduktancia; SPAD - soil plant analysis development; TTC - 2,3,5-trifenil-tetrazólium-klorid

A 115714 sz. projekt a Nemzeti Kutatási, Fejlesztési és Innovációs Alapból biztosított támogatással, a K-16 pályázati program finanszírozásában valósult meg. A tanulmány elkészítését a Magyar Tudományos Akadémia Bolyai János Kutatási Ösztöndíja támogatta. Köszönet illeti a bírálókat a kézirathoz füzött értékes tanácsokért. 


\section{Irodalom}

Al-Karaki, G., McMichael, B. \& ZAK, J., 2004. Field response of wheat to arbuscular mycorrhizal fungi and drought stress. Mycorrhiza. 14. 263-269.

AUGÉ, R. M., 2001. Water relations, drought and vesicular-arbuscular mycorrhizal symbiosis. Mycorrhiza. 11. 3-42.

BRYLA, D. R. \& DUNIWAY, J. M., 1997. Effect of mycorrhizal infection on drought tolerance and recovery in safflower and wheat. Plant and Soil. 197. 95-103.

CHLOUPEK, O., 1972. The relationship between electric capacitance and some other parameters of plant roots. Biologia Plantarum. 14. 227-230.

Cho, K., Toler, H., Lee, J., Ownley, B., Stutz, J. C., Moore, J. L. \& Augé, R. M., 2006. Mycorrhizal symbiosis and response of sorghum plants to combined drought and salinity stress. Journal of Plant Physiology. 163. 517-528.

ClemensSON-Lindell, A., 1994. Triphenyltetrazolium chloride as an indicator of fine-root vitality and environmental stress in coniferous forest stands: Applications and limitations. Plant and Soil. 159. 297-300.

Cseresnyés, I., TAKács, T., VÉGH, R. K., Anton, A. \& RAJKAi, K., 2013. Electrical impedance and capacitance method: a new approach for detection of functional aspects of arbuscular mycorrhizal colonization in maize. European Journal of Soil Biology. 54. 25-31.

CSERESNYÉS, I., RAJKAI, K. \& TAKÁCS, T., 2016. Indirect monitoring of root activity in soybean cultivars under contrasting moisture regimes by measuring electrical capacitance. Acta Physiologiae Plantarum. 38. No. 121., 12 pp.

DALTON, F. N., 1995. In-situ root extent measurements by electrical capacitance methods. Plant and Soil. 173. 157-165.

Ellis, T., Murray, W., Paul, K., Kavalieris, L., Brophy, J., Williams, C. \& MAASS, M., 2013. Electrical capacitance as a rapid non-invasive indicator of root length. Tree Physiology. 33. 3-17.

GONDOR, O. K., JANDA, T. \& SzALAI, G., 2013. Comparative study of viability measurement methods in crop plants. Acta Agronomica Hungarica. 61. 219226.

HeřmanskÁ, A., StŘEdA, T. \& CHLOUPEK, O., 2015. Improved wheat grain yield by a new method of root selection. Agronomy for Sustainable Development. 35. 195-202.

Li, H., Smith, S. E., Holloway, R. E., ZhU, Y. \& SMith, F. A., 2006. Arbuscular mycorrhizal fungi contribute to phosphorus uptake by wheat grown in a phosphorus-fixing soil even in the absense of positive growth responses. New Phytologist. 172. 536-543.

Li, H., Smith, F. A., Dickson, S., Holloway, R. E. \& SMith, S. E., 2008. Plant growth depressions in arbuscular mycorrhizal symbioses: not just caused by carbon drain? New Phytologist. 178. 852-862.

MilchunAS, D. G., 2012. Biases and errors associated with different root production methods and their effects on field estimates of belowground net primary production. In: MANCUSO, S. (ed.): Measuring roots. Springer, Berlin, pp. 303-339. 
MONOSTORI, I., ÁRENDÁs, T., HofFMAn, B., GALIBA, G., GIERCZIK, K., SZIRA, F. \& VÁGÚJFALVI, A., 2016. Relationship between SPAD value and grain yield can be affected by cultivar, environment and soil nitrogen content in wheat. Euphytica. 211. 103-112.

OzIER-LAFOnTAine, H. \& BAJAZET, T., 2005. Analysis of root growth by impedance spectroscopy (EIS). Plant and Soil. 277. 299-313.

PARNISKE, M., 2008. Arbuscular mycorrhiza: the mother of plant root endosymbioses. Nature Reviews Microbiology. 6. 763-775.

Pellegrino, E., ÖPIK, M., BonARI, E. \& ERCOLI, L., 2015. Responses of wheat to arbuscular mycorrhizal fungi: A meta-analysis of field studies from 1975 to 2013. Soil Biology and Biochemistry. 84. 210-217.

PHILlIPS, J. M. \& HAYMAN, D. S., 1970. Improved procedures for clearing roots and staining parasitic and vesicular-arbuscular mycorrhizal fungi for rapid assessment of infection. Transactions of the British Mycological Society. 55. $157-160$.

Postic, F. \& Doussan, C., 2016. Benchmarking electrical methods for rapid estimation of root biomass. Plant Methods. 12. No. 33., 11 pp.

RAJKAI, K., VÉGH, R. K. \& NACSA, T., 2005. Electrical capacitance of roots in relation to plant electrodes, measuring frequency and root media. Acta Agronomica Hungarica. 53. 197-210.

Ryan, M. H., HerwaARden, A. F. VAN, Angus J. F. \& KirkegaARD, J. A., 2005. Reduced growth of autumn-sown wheat in a low-P soil is associated with high colonisation of arbuscular mycorrhizal fungi. Plant and Soil. 270. 275-286.

SMith, S. E. \& SMITH, F. A., 2012. Fresh perspectives on the roles of arbuscular mycorrhizal fungi in plant nutrition and growth. Mycologia. 104. 1-13.

TAKÁCS, T., 2012. Site-specific optimization of arbuscular mycorrhizal fungi mediated phytoremediation. In: ZAIDI, A., WANI, P. A., KHAN, M. S. (eds.): Toxicity of heavy metals to legumes and bioremediation. Springer, Vienna, 179-202.

TalaAt, N. B. \& Shawky, B. T., 2014. Protective effects of arbuscular mycorrhizal fungi on wheat (Triticum aestivum L.) exposed to salinity. Environmental and Experimental Botany. 98. 20-31.

TAWARAYA, K., 2003. Arbuscular mycorrhizal dependency of different plant species and cultivars. Soil Science and Plant Nutrition. 49. 655-668.

Trouvelot, A., Kough, J. L. \& GianinazZi-Pearson, V., 1986. Mesure du taux de mycorhization VA d'un système radiculaire. Recherches et methods d'estimation ayant une signification fonctionnelle. In: GIANINAZZI-PEARSON, V., GianinaZZI, S. (eds.): Physiological and genetical aspects of mycorrhizae. INRA, Paris, 217-221.

Uddling, J., Gelang-Alfredsson, J., PiIKKI, K. \& PleiJel, H., 2007. Evaluating the relationship between leaf chlorophyll concentration and SPAD-502 chlorophyll meter readings. Photosynthesis Research. 91. 37-46.

Vamerali, T., Bandiera, M., Coletto, L., Zanetti, F., Dickinson, N. M. \& MosCA, G., 2009. Phytoremediation trials on metal- and arsenic-contaminated pyrite wastes (Torvicosa, Italy). Environmental Pollution. 157. 887-894. 


\title{
Monitoring the effect of drought stress and mycorrhizal fungi on wheat root growth using the electrical capacitance method
}

\author{
I. CSERESNYÉs, T. TAKÁCS, R. KovÁCS, A. FÜZY, K. RAJKAI
}

Institute for Soil Sciences and Agricultural Chemistry, Centre for Agricultural Research, Hungarian Academy of Sciences, Budapest (Hungary)

\section{Summary}

A pot experiment was designed to evaluate the effects of drought exposure and arbuscular mycorrhizal fungal (AMF) colonization on wheat root growth by monitoring the electrical capacitance $\left(\mathrm{C}_{\mathrm{R}}\right)$ of the root-soil system in situ.

The experiment was randomized in complete blocks $(\mathrm{n}=12)$ with two wheat cultivars (Mv. Hombár winter wheat and TC 33 spring wheat), two water regimes (well-watered and drought-stressed) and two AMF treatments (inoculated and noninoculated). $C_{R}$ was measured regularly over the growing season, and stomatal conductance and leaf chlorophyll content (in SPAD value) were also investigated. After harvest, TTC test was applied to evaluate the root vitality, while AMF root colonization was estimated microscopically. Root and shoot dry mass were determined terminally.

Water deprivation significantly decreased the root mass of the cultivars (by 9-35\%); the change was clearly indicated by the lower value of $C_{R}$. The droughtinduced reduction both in $\mathrm{C}_{\mathrm{R}}$ and plant biomass proved to be higher in cultivar TC 33 than in Mv. Hombár. Plant regeneration after drought exposure and differences in root growth dynamics among the cultivars was revealed by monitoring $C_{R}$. AMF inoculation caused a $29-42 \%$ decrease in biomass production, presumably due to the intensive (84-87\%) root colonization and to the conditions of plant cultivation (e.g. severe drought). Fungal inoculation led to enhanced stomatal conductance and root vitality in well-watered plants. Drought resulted in reduced root vitality. Leaf chlorophyll content was chiefly dependent on cultivar, with higher SPAD values for Mv. Hombár. Strong linear relationships $\left(\mathrm{R}^{2}=0.792-0.865\right)$ were found between root dry mass and $C_{R}$. The regression slope was steeper for cultivar TC 33, likely due to the higher specific water uptake rate associated with higher shoot biomass.

The results demonstrated the potential of $C_{R}$ measurement for monitoring root growth and detecting the influence of environmental conditions on root activity. The non-intrusive method could be a useful approach for research in plant physiology and agriculture.

Keywords: arbuscular mycorrhizal fungi (AMF), electrical capacitance, root activity, root growth, drought stress 


\section{Tables and figures}

Fig. 1. Changes in root electrical capacitance $\left(\mathrm{C}_{\mathrm{R}}\right.$ in nanofarads) with plant age in different wheat cultivars $(M$ and $T)$ grown under well-watered $(W)$ or droughtstressed $(D)$ conditions and either non-inoculated $(-)$ or inoculated (+) with arbuscular mycorrhizal fungi (AMF). Vertical bars show standard deviations. (1) Plant age in days.

Fig. 2. (A) Stomatal conductance $\left(g_{\mathrm{s}}\right)$, (B) SPAD chlorophyll meter reading, (C) root vitality (absorbance in TTC test) and (D) the intensity (M\%) and arbuscularity (A\%) of AMF root colonization in various wheat treatments. Vertical bars show standard deviations. See Fig. 1 for treatment legend. (1) SPAD value. (2) Absorbance per $g$ of fresh root. (3) AMF colonization.

Fig. 3. (A) Root and shoot dry mass and (B) root/shoot ratio in various wheat treatments. Vertical bars show standard deviations. See Fig. 1 for treatment legend. (C) Relation between root electrical capacitance $\left(\mathrm{C}_{\mathrm{R}}\right)$ and root dry mass for wheat cultivars $M$ and $T$ (dashed and solid line, respectively). (1) Dry mass. (2) Root. (3) Shoot. (4) Root/shoot ratio. (5) Root dry mass. 